\title{
Russian Cultural Marking of the International Scene: The Soft Power to the Test (2000-2018)
}

\author{
J.C. Kouma \\ Peoples' Friendship University of Russia (RUDN University) \\ Miklukho-Maklaya str., 6, Moscow, Russian Federation, 117198
}

\begin{abstract}
Since the mid-1990s, and even more Vladimir Putin's accession to the presidency, reaffirmation and recognition of Russia's status as a great power has been erected as an existential political imperative. The restoration of Russia's global influence is one of the parts of this high-powered policy implemented by the authorities. It manifests itself repeatedly through hard power initiatives outside national borders in Georgia, Ukraine or Syria. But the "color revolutions" in the post-Soviet space, primarily the Orange Revolution of 2004, prompt the Russian government to rethink its foreign policy in order to project a better image of Russia abroad. This late awareness is reflected in the adoption of a clean soft power strategy and its main key instruments are created during the second term of Vladimir Putin (20042008). The notion of soft power will be institutionalized in the Foreign Policy Concept of the Russian Federation on February 12, 2013. This article is therefore intended as a contribution to the analysis of the issues surrounding the cultural variable in foreign policy. of the Russian Federation. It is therefore more precisely his ambition to decipher the motives underlying the mobilization of resources for the purpose of cultural outreach by Russia. A country with many contrasts and, moreover, in a world cultural field traditionally controlled by strong Western powers, Russia has opted for soft power, with the triple vision of making its way, to feed its current rise and to pose as a "responsible" and "conciliatory" power. For the twelfth largest economic power in the world, it is also a question of reducing the mistrust and criticism that its presence already arouses on the international scene. The choice made on the cultural variable is therefore not insignificant; because, it is a strategy, through which Russia would like to build, if not regain its greatness of yesteryear.
\end{abstract}

Keywords: Russia, foreign policy, soft power, Power, culture, cooperation, sport

\section{The motives that underlie Russia's international cultural influence}

Russia is an exceptional mosaic of regions with their own cultural roots, a past and a cultural present of their own. It is around the 16th century that the state built by the Muscovite power changes scale and becomes a territory henceforth

(C) Kouma J.C., 2019

This work is licensed under a Creative Commons Attribution 4.0 International License https://creativecommons.org/licenses/by/4.0/ 
associated with the notion of immensity. From the eighteenth century to the present day, Russia is the largest state in the world [1]. The Eurasian "statecontinent" status is not without consequences in terms of perception of the world. It has often reinforced, both among Russian thinkers and governments, the temptation to make "a world in itself" [1], when we know that ideology [2] serves to conceal intentions, justify actions, mobilize people and recruit supporters across borders; a screen, an argument, a cement and a weapon. In the light of realistic theories, the elements of the power of a state are diverse. Among those listed by Hans Morgenthau, figure indeed geography. This is what we will try to develop here keeping in mind this fundamental axis linking space and power, the power expressed in the space policies implemented by Russia. Space is like a palette where the degrees of state power can be expressed. Thus, to consider the stakes that represent the Russian territory leads us to question its attraction, its credibility that can explain its projection on the international scene.

In Russian academic literature, the concept of soft power seems recent and hardly convincing [3; 4]. In fact, it is not new. Through its ideology, the USSR exerted a real attraction, even during its last years of existence thanks to the outstanding communicator that was Mikhail Gorbachev. Boris Yeltsin was also very concerned about the image of his country in the world and he managed to impose the idea that Russia continued to be one of the big ones of this world. The domestic and international positions of the latter are deteriorating, but success has been limited. The double enlargement of the Atlantic Alliance and the European Union as well as the color revolutions in Georgia and Ukraine have rekindled reflection on the issue. They clearly mean that Russia has to change the image it has of itself in the world, modernize the means at its disposal and acquire new instruments. Because, every self-respecting country builds its identity.

Russia, unlike the countries of Western Europe, is experiencing a period of radical transformation of its social fabric. Cultural policy has changed significantly in the last decade as a result of political and economic reforms. The two pivotal dates are 1985 and $1991^{1}$. It was in 1985 that perestroika, that is the transformation of state policy in the economic, social and cultural sphere. Attempts to change and reform the Soviet political and economic system led to an exacerbation of internal contradictions and ultimately to the collapse of 1991, which saw the USSR disappear. At the same time, the cultural policy implemented in present-day Russia could only bear the imprint of the past. Thus from the year 2000, the popular support to the political and state project of Vladimir Putin, which combines restoration of national values, political intransigence in the face of any threat of state monopoly and the desire to restore the status of great power of Russia, is manifested ([5]. From then on, the development of the cultural factor by Russia responds to a logic that consists in wanting to unify the world to its cultural values, in order to achieve the results that it can not have through the political struggles and the military force. Even though the policy seems to use culture for

${ }^{1}$ Cultural Policy of the Russian Federation. Council of Cultural Cooperation; Strasbourg; 1998. 
strategic purposes, for Russia, it also aims to improve its image by helping mutual understanding and denouncing the stereotypes, prejudices and prejudices she is a victim. And above all, as Alain Peyrefitte points out, "the Western public is afflicted with myopia made up of prejudices, ideological passions and above all ignorance ..." [6]. Russia wants, through culture, to defuse ideological criticism and recover the greatness of the past. This further confirms Marie Dousset's statement that: "nostalgic of Russia's past greatness, Putin dreams of giving it back a place of choice on the international stage" [7].

\section{Russian Soft Power Instruments}

The culture since the end of the Cold War, occupies a pre-eminent place in the organization of the international society. Each actor tends to value the cultural variable and Luc Sindjoun thinks in this respect that the cultural power has acquired a major importance in international relations after the Cold War and especially after September 11, 2001. He also underlines that this expression refers to " a set of capabilities based on mastery either by a group in any form whatsoever (state, network, company, international organization, etc.) or by individuals, ways of doing, thinking and to feel able to enable him to orient a social relation to their symbolic or material profit. It is the chance of the triumph of the will, based on the control of meanings, norms and values, objects of identity" [8]. For J. Nye "power in the twenty-first century will be based on a mixture of hard and soft resources" [9]. Today, power rests less on military domination alone, concentrating instead on several chess-boards, certainly military, but also economic, political, media, cultural and symbolic. According to Nye, "the power of co-optation - the ability to steer what others want - often depends on the attraction of culture and ideology to other peoples, or the ability to manipulate political choices so that actors can express some of their desires only because they appear unrealistic" [10]. To this end, it is undeniably accepted that the cultural aspect is among the official declarations proclaimed by the Russian Government: the use of "soft power" instruments to solve foreign policy problems becomes an integral part current international politics, that is, the use of civil society capabilities, information and communication technologies and technologies, social and other, in addition to traditional diplomatic methods ${ }^{2}$.

To this end, Russia has been developing since 2000 a set of tools to make its emergence not threatening, but attractive. Some examples of this soft approach are public diplomacy, exchange programs, development aid, humanitarian aid, military contacts, media. Public diplomacy is now an integral part of Russian foreign policy. In 2003-2004, she is looking for new ways of doing things. In areas very different from each other, it relaunches the policies implemented and sets up new channels and relays. His numerous and eclectic initiatives aim to develop a di-

${ }^{2}$ The Foreign Policy Concept of the Russian Federation (approved by Russian President Vladimir Putin on November 30, 2016) 
plomacy of influence, to gain support for his ideas and, to create an environment that is favorable to him, to weigh, through representations and attractiveness, on the definition of policies towards it. Thus Russia invests the means of which it has a simple concept, that of shared reflection. To carry out its project, the country will put in place various essential resources such as:

Russkyi Mir Foundation (Russian World) and Rossotrudnichestvo: Created in 2007 and 2008 respectively, the Russkyi Mir Foundation (Russian World) and the Federal Agency for International Humanitarian Cooperation (Rossotrudnichestvo) have given a new impetus to the promotion of the Russian language, especially in the post-Soviet the reception of foreign students, that is to say the training of the elites and the organization of commemorations of great events which aims to maintain symbols of the greatness of Russia [11]. They aim to promote research in education and aim to create or develop concrete objects, symbolic devices, practices, situations, educational and pedagogical. Luc Sindjoun believes that education "refers to the formation and transmission of knowledge: it is the framework par excellence of labeling culture" [8]. The training and development of foreign students is one of the strategic aspects of Rossotrudnitchestvo. This training aims to create resources that promote the development of southern countries. The Russkyi Mir Foundation strives to develop a sense of Russian culture, a certain intelligibility or a certain understanding, through an effort of global reflection, intuition and sensitive listening, which goes beyond the natural, human and social sciences, without excluding them.

Russia Today (RT): This 24-hour streaming television channel in English from December 2005, then in Arabic from 2007 and in Spanish from 2009 has modernized the Russian outdoor audiovisual system]. It must be said that Russia has made the choice, here again, to set up a satellite channel that can largely compete with the prestigious foreign channels (CNN, France 24, BBC, etc.). Thus, the chain allows the borders to be opened in a symbolic way to let information pass and to understand what is going on elsewhere. It seems that it allows Russia to join the globalization and to take a place in this world that has often turned its back. It should be noted that this channel allows its viewers to flourish and sharpen a reflection of their own. Moreover, it is certain that it must certainly frighten the majority of the countries of the world, especially those of the Western world, because it enjoys an influence that gives it a role in the Russian street.

In view of the foregoing, since the USSR was a predominantly military power, the Russian ruling elites became more familiar with hard power and "the ability to influence what others do" through coercion or of the reward, that with the soft power and "the ability to influence what others want [...] to seduce and attract [...], attraction often leading to consent and imitation" [12; 13].

Investment in international events: The communication and the cultural have become determinant in the outcome of the battles that are won today. Thus, Russia sets up and hosts projects whose mission is to strengthen its presence in the world, to participate in all the major debates of the world, to spread a "Russian thought" and to rectify what it considers to be the misconceptions that circulate on 
his account. Since 2000, Elle has relied more on sports, scientific and cultural records such as: Sochi 2014 Olympic Winter Games, 2017 Football Confederation Cup, 19th World Youth Festival and 2017 Students Festival Sochi and the 2018 FIFA World Cup. This is to enhance its attractiveness through innovation, and a branding policy. Indeed, the image of a country is the perception that one has of it. From then on, it can vary from one individual to another. The image does not escape the States. In fact, nothing prevents them from caring for this image, to develop it, to use it to achieve certain objectives. Other factors may affect the image of a country or a state. This is true of the people of this country, its culture, history, cuisine, flagship products, or even its level of development [14]. The image and reputation of a country become indispensable to the politics of a state that wants to be prosperous and influential [15]. Russia is doing it, without renouncing the hard power instruments.

The image is part of Russia's nation-branding policy, implemented as a result of Sochi's candidacy for the organization of the 2014 Olympic Games. The concept of nation branding refers to the policy of promoting the image of a state, using "reputation management" tools usually mobilized by private companies. It is therefore a convincing example of Russia's strategy of cultural influence in the world, which combines with its diplomatic influences (the frequent exchange of visits at the highest level) to defeat Western hegemony. As Alain Plantey notes, "competition between nations does not spare the field of thought insofar as the spread of speech, image, and idea can make it possible to influence politics and strategies of states" [16]. To this end, no country has as much impact on the organization of international events as Russia since the beginning of the millennium.

Russia has been able to adopt and successfully implement a new strategy, that of branding. The sporting niche is one of the most prized by state brands and Russia is no exception to the rule. The sport is considered by the Russian authorities as one of the sure ways to achieve a high international visibility. Russia is giving itself the means to multiply competitions and accommodate a maximum of major sporting events. With significant financial surpluses, the country's leaders use significant resources both to meet the huge consumption and investment needs, and at the same time to serve them for greater international visibility. It is for this purpose that Russia is betting on sport. For Jean-Jacques Bozonnet, "globalized professional sport has become for many states one of the best vectors of soft power" [17]. What Pascal Boniface confirms: "Sport has become an instrument of soft power, this soft power that has become the new and subtle form of power. Each state tries to attract the attention, the respect and the sympathy of the other nations thanks to its champions who have become true international stars, known and admired on the five continents. Living icons of the global village that is today the planet with the rise of communication and information technologies" [18].

In addition to the Olympic games and football competitions, other cultural activities are in the spotlight in Russia. The 2014 Sochi Olympic Winter Games (OJ) provided good international visibility for Russia. This event presents a geopolitical dimension. "With the Olympics, Putin is playing Russia's place in the 
world cherishing the hope of recreating a kind of common market around Russia that would be an alternative to the European Union"'. Although apolitical character of this event, but it should be noted that this is simply a myth. What makes Pascal Boniface say that: "from the moment when we bring together, for a competition, citizens from different countries, the event is inevitably political" [18]. Moreover, he says, "the official ban on the intrusion of politics in the Games concerns athletes, not States. The first, who will quickly become ambassadors in shorts, are obliged to reserve. States remain free to determine their political line and the IOC, whether in accepting or excluding national delegations or choosing the host city, will make decisions based on geostrategic criteria" [18]. So to speak, the power of the image has Exponentially believed after the Second World War and the Olympics marked the spirits, proving the extraordinary interweaving of politics and sport in the Olympic universe.

The stakes of football, be they political, economic and even geopolitical, have long gone beyond purely sports. Football competitions have, moreover, been widely used by States as signals of rapprochement. Subject of passion and sometimes overflowing, football contributes to developing relations between peoples [19]. This "sport king" proved that it could constitute, for some states, like Russia, not only a formidable relay for its image in the world but also an instrument that promotes its discovery. Football is the image of the nation, its reflection [19] and thus contributes to the international influence of a state. This is what makes Didier Lucas say that "in the age of soft power, football is probably one of the best instruments of the radiation of a state" [20]. It is the international football competitions in the framework of the June-July 2017 Confederations Cup and the 2018 World Cup, which will allow Russia to discover more.

Always in perfect coherence, Russia has chosen to allow politicians, diplomats, young people, intellectuals and students from around the world to come together to think together about global issues, or simply through essential concepts. This sensitivity that Russian leaders bring makes it possible to create means to produce a common reflection that can increase the efficiency of human work. These times of work and reflection must allow people to enrich themselves and become actors in this world. The XIX World Festival of Youth and Students of 2017 Sochi, already organized in 1957 and 1985 in Russia, brought together the different nations, with one goal, that of thinking together. The program of this international event included youth meetings in more than 70 venues to discuss multiple themes, including "Culture and Globalization", "The Global Economy", "The Knowledge Economy", "The World". development of public institutions and "politics and international security". An International Forum of Youth Cinema, Artistic and Cultural Exhibitions and various sports and youth activities were organized in Yekaterinburg, Simferopol, Sevastopol and other cities representing 15 Russian regions. Vladimir Putin has therefore made a choice for his country, that

${ }^{3}$ Les Echos. 27.01.2014. 
of allowing different people to come together to reflect on global issues. From now on, it will be necessary to count with Russia "unavoidable country". This event is part of the charm offensive, aimed at making Russia more attractive and less intimidating. This event is part of the""soft power" resources and therefore corresponds to the attraction and seduction capacity exercised by the Russian cultural model. And the objectives assigned to this great world meeting are proving to be a vector for the development of friendship ties between Russia and the rest of the world. As such, during the opening ceremony of the festival, Vladimir Putin said that this meeting is a link between countries committed to freedom and solidarity. The organization of the festival cost a total of 4.5 billion rubles to the Russian budget. The country has financed the holding of all events in Sochi as well as the accommodation and meals of the participants in hotels located in Adler, not far from the Olympic Park. The total number of participants is approximately 30,000, including 20,000 delegates (10,000 Russians and 10,000 foreigners), 7,000 volunteers, and a large number of speakers and guests. Vladimir Putin declared that the countries of the world must stop spending resources in a "useless" rivalry: "we see each other as adversaries, and instead of cooperating and solving problems that concern us all, we devote a large part of our resources to secondary things, we must strive to consider each other as partners" 4 . This festival has therefore participated, through its activities, in the implementation of the soft dimension of Russian power. This festival contributed to the cultural influence of Russia in the world, at the same time as it was one of the strong instruments of its power.

In short, to evoke the "return" of Russia on the international scene is today a commonplace. In Russia, this phenomenon is largely put to the credit of Vladimir Putin, a majority of his fellow citizens believing that his policy allowed the recovery of the country after the "disorders" of US years [11]. In Europe and the United States, this "return" raises questions and sometimes concerns. Russia is returning to its ambitions of power at a time when rising oil prices are changing its relationship with the world. It is positioning itself, along with the major industrialized countries and emerging powers, as one of the centers of power in a multipolar world whose work it is trying to demonstrate. Russian policy seems very proactive, pragmatic and focused. It relies, as we mentioned above, on certain resources. Nevertheless, the Russian cultural power is articulated as exclusively around the state in the governmental sense of the term. And, as Samuel Huntington points out, "the power of a State is normally evaluated by measuring the resources available to it over those possessed by other States that it tries to influence" [21]. Developing a soft power by Russia is a long-term task. Without prejudging the future, we note that the initiatives taken are facing serious difficulties. To move from propaganda, omnipresent during the time of the Soviet Union, to the information and the debate of ideas turns out in particular very complex and that their effects are limited. The very deteriorated image of Russia in the world

${ }^{4}$ Mitina Daria, Member of the National Organizing Committee and President of the Russian Communist Youth Union (RKSM) in RBC Daily. 16.10.2017. 
bears witness to this. In December 2004, a survey conducted in 23 countries revealed that Russia was only marginally perceived as having a positive influence. Subsequently, his image has deteriorated further. In Europe, the decline is general. One of the reasons for Western discontent is that Russia seems to represent a form of alternative development that is popular with the majority of humanity [22]. For political scientist Sergei Karaganov, "Russia is one of the few countries to attract a huge number of people through its efforts to maintain its independence and sovereignty. It is a powerful pole of attraction. It intends to become again master of its destiny, to weigh on the decision and to be recognized like a driving element of a more 'just' international order. A dream of power, but also of magnitude. But greatness is not a matter of discourse, but of objectives and results. What we must recognize is that contemporary Russia stands out as much from the traditions of the time of the autocracy, where orthodoxy was the state religion, that the Soviet era, marked by the monopoly of the Marxist-Leninist ideology" [23]. However, are the soft power resources mobilized by Vladimir Putin commensurate with Russia's quest for power? The cultural rise and then the political supremacy at the international level of Vladimir Putin could be consolidated after reelection at the head of the Russian Federation for a new mandate of 06 years of 18 March 2018.

\section{REFERENCES}

[1] Pinot A., Reveillard C. (eds.) Russia Yesterday and Today. Cross Perceptions. Paris: L'Harmattan; 2016 (In Fr.).

[2] Gauchon P., Huissoud J.M. The 100 Words of Geopolitics. Paris: PUF; 2008 (In Fr.).

[3] Tsygankov A. If Not by Tanks, then by Banks? The Role of Soft Power in Putin's Foreign Policy. Europe-Asia Studies. 2006; 58; 7: 1079-1099.

[4] Karaganov S. Russia in Euro-Atlantic Region. Rossiyskaya Gazeta. 24.11.2009 (In Russ.).

[5] Le Huerou A., Sieca-Kozlowski E. Military Culture and Patriotism of Today's Russia, Paris: Karthala; 2008 (In Fr.).

[6] Bessière S. China at the Dawn of the Twenty-first Century: The Return of Power? Paris: L'Harmattan; 2005 (In Fr.).

[7] Dousset M. Vladimir Putin, Ready for Anything for "His" Great Russia. Geopolis Africa. 22.08.2013.

[8] Sindjoun L. In Search of Cultural Power in National Relations: A Test of Characterization of the Concept and Apprehension of the Phenomenon. Cameroon Journal of International Politics. 2007; 1: 20-21.

[9] Nye J. The Paradox of American Power: Why the World? Only Superpower Cannot Go It Alone. Oxford: Oxford University Press; 2002.

[10] Nye J. The American Leadership: When the Rules of the Game Change. Nancy: Presses Universitaires de Nancy; 1992 (In Fr.).

[11] Tingui A. Moscow and the World: The Ambition of Greatness: An Illusion? Paris: CERI; 2008 (In Fr.).

[12] Nye J. Soft Power. The Means to Success in World Politics. New York: Public Affairs; 2004.

[13] Nye J. The Future of Power. New York: Public Affairs; 2011.

[14] Aker D-A. Managing Brand Equity, Capitalizing on the Value of a Brand Name. New York: The Free Press; 1991. 
[15] Van Ham P. The Rise of the Brand State, the Postmodern Politics of Image and Reputation. Global Policy Forum. 2001.

[16] Plantey A. Politics Between Nations: Principles of Diplomacy. Paris: Pedone; 1991 (In Fr.).

[17] Bozonnet J-J. Sport, a Geopolitical Issue. Le Monde Histoire. 08.01.2014 (In Fr.).

[18] Boniface P. JO Policies. Jean-Claude Gawsewitch Publisher; 15.05.2012 (In Fr.).

[19] Boniface P. (eds.) The Earth Is Round Like a Balloon: Geopolitics of Football. Paris: Editions du Seuil; 2002 (In Fr.).

[20] Lucas D. Editorial. Geoeconomics. 2010; 54: 5-6.

[21] Huntington S. Introduction to International Relations. Paris: Seuil; 1987 (In Fr.).

[22] Grynszpan E. Russian Soft Power Scores Points. Time. Moscow. 16.06.2016.

[23] Garbe E. From Stalin to Putin. Paris: Publibook; 2003 (In Fr.).

Научная статья

\title{
Культурная маркировка России на международной арене: испытание мягкой силы (2000-2018)
}

\author{
Ж.К. Кума \\ Российский университет дружбы народов \\ ул. Миклухо-Маклая, 6, Москва, Россия, 117198
}

\begin{abstract}
Аннотация. Автор утверждает, что со второй половины 1990-х годов, и особенно с момента вступления В.В. Путина на пост президента, международное подтверждение и признание статуса России как великой державы было возведено в ранг экзистенциального внешнеполитического императива. Восстановление глобального влияния России - одна из составляющих этой политики, проводимой российскими властями. Однако «цветные революции» на постсоветском пространстве, в первую очередь «Оранжевая революция» 2004 года на Украине, заставили российское руководство переосмыслить отдельные императивы внешней политики для того, чтобы спроецировать за рубежом лучший образ России. Данные приоритеты нашли отражение в программных документах во время второго президентского срока В.В. Путина (20042008 гг.). Понятие «мягкой силы» будет институционализировано в Концепции внешней политики Российской Федерации от 12 февраля 2013 года. Данная статья призвана внести вклад в анализ проблем, связанных с культурной переменной во внешней политике Российской Федерации. Автор полагает, что в мировом культурном поле, традиционно контролируемом сильными западными державами, Россия выбрала мягкую силу на основе видения своего особенного пути, своей истории культуры и многочисленных достижений, представляя себя «ответственной» и «примиряющей» державой.
\end{abstract}

Ключевые слова: Россия, внешняя политика, мягкая сила, власть, культура, сотрудничество, спорт

\section{Сведения об авторе:}

Жан Коттен Кума - аспирант кафедры сравнительной политологии Российского университета дружбы народов (ORCID ID: 0000-0001-5717-3023) (e-mail: cottingelin@yahoo.fr). 


\section{Information about the author:}

Jean Cottin Kouma - PhD Student of the Department of Comparative Politics, Peoples' Friendship University of Russia (RUDN University) (Russian Federation) (ORCID: 00000001-5717-3023) (e-mail: cottingelin@yahoo.fr).

\section{Для цитирования:}

Kouma J.C. Russian Cultural Marking of the International Scene: The Soft Power to the Test (2000-2018) // Вестник Российского университета дружбы народов. Серия: Государственное и муниципальное управление. 2019. Т. 6. № 4. С. 356-365. DOI: 10.22363/2312-8313-2019-6-4-356-365

\section{For citation:}

Kouma J.C. Russian Cultural Marking of the International Scene: The Soft Power to the Test (2000-2018). RUDN Journal of Public Administration. 2019; 6 (4): 356-365. DOI: 10.22363/2312-8313-2019-6-4-356-365 